\title{
RESTRICTION BY OBJECT: A RESTRICTION BASED PURELY ON EXPERIENCE OR ALSO ON EFFECTS?
}

\author{
JOAR LINDÉN*
}

This article claims that restriction by object is a concept purely based on experience and for which the effects of a disputed agreement are not relevant. While an examination of an agreement's effects requires a counterfactual assessment, a restriction by object does not. Decisive for a restriction by object is whether a disputed agreement may be subordinated under a by object type of collusion, considering the agreement's content, objectives, and context, albeit not effects. By object types of collusion can be described as general rules which are inductively based on the experience that agreements with certain content, objectives, and context are sufficiently likely sufficiently barmful to competition.

\section{INTRODUCTION}

Article 101 of the Treaty on the Functioning of the European Union (henceforth "TFEU”) establishes a prohibition of agreements between undertakings ${ }^{1}$ that have as their object or effect the restriction of competition on the internal market. ${ }^{2}$ If a restriction by object or effect is established, the disputed agreement is void, ${ }^{3}$ unless the defendant ${ }^{4}$ proves that the agreement is justified according to Article 101(3) TFEU. ${ }^{5}$ Restrictions by object and effect are alternative, not cumulative. ${ }^{6}$ Additionally, they are sequential, in that the latter is following the prior. First, one considered whether there is a restriction by object. Only if the answer is negative, one should consider effects. ${ }^{7}$ However, establishing a restriction by object does not prevent an examination also (but separately) of a restriction by effect. ${ }^{8}$ Consequently, restrictions by object must in principle be distinguished from restrictions by effects.

\footnotetext{
*LLM Faculty of Law, Lund University and associate in EU competition law at Mannheimer Swartling. This article is based on a master thesis written by Joar Lindén within the master programme in European Business Law at Lund University. The usual disclaimer applies.

${ }^{1}$ In this article, the concept of agreements between undertakings includes also concerted practices and decisions by associations of undertakings.

2 See Article 101(1) TFEU.

${ }^{3}$ See Article 101(2) TFEU.

${ }^{4}$ In this article, the concept of defendant refers to the undertaking alleged of an infringement of EU competition law.

${ }^{5}$ See Alison Jones, Brenda Sufrin, and Niamh Dunne, Jones \& Sufrin's EU Competition Law: Text, Cases, and Materials (7th edn, Oxford University Press 2019) 207 and 261ff.

${ }^{6}$ See Case 56/65 Société Technique Minière v Maschinenban Ulm ECLI:EU:C:1966:38, 249; Case C-209/07 Beef Industry Development and Barry Brothers ECLI:EU:C:2008:643, para 15; Case C-172/14 ING Pensii ECLI:EU:C:2015:484, para 29; C-228/18 Budapest Bank and Others ECLI:EU:C:2020:265, para 33. ${ }^{7}$ See eg Case C-8/08 T-Mobile Netherlands and Others ECLI:EU:C:2009:343, para 28; C-172/14 ING Pensii (n 6), para 30; David Bailey, 'Article 101(1)' in Bailey D, and John LE (eds), Bellamy \& Child: European Union Law of Competition (8th edn, Oxford University Press 2018), 164f.; Guidelines on the application of Article 101 of the Treaty on the Functioning of the European Union to technology transfer agreements [2014] OJ C 89/3 (henceforth Technology Transfer Guidelines), paras 13-15.

${ }^{8}$ See C-228/18 Budapest Bank (n 6), para 40.
} 
Yet, the distinction is not clear. Despite restrictions by object having been described as "the most serious violations" of EU competition law, confusion exists in legal doctrine. Confusion concerns particularly the delimitation between restrictions by object and effect, which several doctrinal authors consider being blurred. ${ }^{10}$ Simultaneously, the Court of Justice (henceforth "CJ") appears satisfied with how things currently stand, by continuously resorting to practically standardised expressions on the definition of restrictions by object. ${ }^{11}$

In three new judgements, however, the $\mathrm{CJ}$ has added an important explanation: restrictions by object, which are based on content, objectives, and context of the disputed agreement, are different from restrictions by effect in that no counterfactual assessment is to be undertaken. ${ }^{12}$ Thus, this is a suitable time for revisiting the concept of restriction by object on a fundamental basis, in means of elucidating its meaning. In this article, I argue that restrictions by object can be construed as based only on experience and thereby as being fully detached from effects in casu.

However, before proceeding to the main content, I will provide two basic points of information about restrictions by object. Firstly, restriction by object is strictly interpreted. ${ }^{13}$ Secondly, the aim of restrictions by object may be described as to pursue legal certainty (including deterrence), by providing predictability, and procedural economy, by easing the burden on responsible authorities. ${ }^{14}$ Hence, the concept of restrictions by object may facilitate combatting of anti-competitive conduct and, thereby, the overarching objective of Article 101 TFEU of ensuring that competition in the internal market remains undistorted. ${ }^{15}$ Simultaneously, it may entail over-enforcement by prohibiting conduct not being anti-

\footnotetext{
${ }_{9}$ See Filippo Amato, 'Defining Agreements and Concerted Practices Restricting Competition in EU Competition Law' in Cortese B (ed), EU competition law: Between Public and Private Enforcement (Kluwer Law International 2013), 39.

${ }^{10}$ See Van Bael \& Bellis, Competition Law of the European Union (6th edn, Kluwer Law International 2021) 63f.; Jones, Sufrin, and Dunne (n 5), 225ff.; Bailey, Bellamy \& Child (n 7), 167; Richard Whish, and David Bailey, Competition Law (8th edn, Oxford University Press 2018), 125f.; Maria Ioannidou, and Julian Nowag, 'Can two wrongs make it right? Reconsidering minimum resale price maintenance in the light of Allianz Hungária' (2015) 11(2-3) European Competition Journal 340.

11 See eg Case C-591/16 P Lundbeck v Commission ECLI:EU:C:2021:243, para 112; Case C-228/18 Budapest Bank (n 6), paras 51-55; Case C-307/18 Generics (UK) and Others ECLI:EU:C:2020:52, paras 64-68; Case C-345/14 Maxima Latvija ECLI:EU:C:2015:784, paras 16-20; Case C-67/13 P CB v Commission ECLI:EU:C:2014:2204, paras 48-53 and 58.

12 See C-591/16 P Lundbeck (n 11), paras 139-141; C-601/16 P Arrow Group and Arrow Generics v Commission ECLI:EU:C:2021:244, paras 84-78; C-611/16 P Xellia Pharmaceuticals and Alpharma v Commission ECLI:EU:C:2021:245, paras 115-117.

${ }^{13}$ See eg C-67/13 P CB (n 11), para 58; C-307/18 Generics (n 11), para 68; C-228/18 Budapest Bank (n 6), para 54.

${ }^{14}$ See C-67/13P CB (n 11), opinion of AG Wahl ECLI:EU:C:2014:1958, para 35; C-8/08 T-Mobile (n 7), opinion of AG Kokott ECLI:EU:C:2009:110, para 43; Van Bael \& Bellis (n 10), 62; Whish and Bailey (n 10), 127; Olga Stefanowicz, 'Guidance on the Limits for the Use of Restrictive Clauses in Commercial Lease Agreements: Once Again on Restrictions by Object' (2016) 9(14) Yearbook of Antitrust and Regulatory Studies 279, 286; comp Maria-Corina Wahlin, 'Post-Cartes Bancaires: Restrictions by Object and the Concept of Vertical Hardcore Restrictions' (2014) 13(4) Comp Law 329, 340; David Bailey 'Restrictions of Competition by Object under Article 101 TFEU’ (2012) 49(2) CML Rev 559, 560.

15 See on the overarching objective C-194/14 P AC-Treuband v Commission ECLI:EU:C:2015:717, para 36; see also Case 6/72 Europemballage Corporation and Continental Can Company v Commission ECLI:EU:C:1973:22, paras 23-25; Protocol (No 27) on the internal market and competition [2008] OJ C 115/309; Bailey, Bellamy \& Child (n 7), 10; Jones, Sufrin, and Dunne (n 5), 42.
} 
competitive (henceforth "false positives"). Accordingly, a balance between facilitating enforcement and preventing incorrect enforcement is warranted. ${ }^{16}$

In the following, I explore the concept of restriction by object and its relation to effects. Firstly, I explain restrictions by object as fundamentally being about experience - a disputed agreement is restrictive by object only if subsumed under a by object type of collusion (section 2). Secondly, I develop the relationship to experience by exploring the concept of by object types of collusions; I describe those types of collusions as inductively created general rules based on the clustering of collusions which are by experience sufficiently likely to cause sufficient harm to competition (section 3). Thirdly, I examine how to subsume a disputed agreement under a by object type of collusion (section 4). Fourthly, I consider the division of the burden of proof for subsuming a disputed agreement under a by object type of collusion (section 5). Lastly, some elaborating and summarizing remarks conclude the article (section 6).

\section{RESTRICTIONS BY OBJECT AS FUNDAMENTALLY ABOUT EXPERIENCE}

The wording of Article 101(1) TFEU does not reveal the underlying complexity of the concept of restriction by object. Theoretically perplexing, the concept of restriction by object has been defined objectively. Subjective intentions of the parties merely constitute potential proof but cannot be decisive $;^{17}$ a finding of pro-competitive (and lack of anti-competitive) subjective intent does not as such prevent a finding of a restriction by object. ${ }^{18}$ Instead, the concept of restriction by object is based on "the objective meaning and purpose of the agreement considered in the economic context in which it is to be applied". ${ }^{19}$ Accepting this objective definition, the question is what requirements must be met for establishing that an agreement objectively pursues the object of restricting competition (in other words an anticompetitive object).

It appears that 'revealing a sufficient degree of harm to competition' constitutes the summarising epithet of what is required to establish a restriction by object. More specifically, in case C-228/18 Budapest Bank, the CJ proclaimed that "the essential legal criterion" 20 is that the agreement "reveals in itself a sufficient degree of harm to competition for it to be considered that it is not necessary to assess its effects". ${ }^{21}$ Read in its context, it appears that "certain types" 22 of collusion reveal such harm. The rationale is that "certain collusive

\footnotetext{
${ }^{16}$ See Jones, Sufrin, and Dunne (n 2), 55f., 215ff, and 234f.; comp. C-67/13 P CB (n 11), para 58.

17 See eg C-209/07 BIDS (n 6), para 21; Bailey, 'Restrictions of Competition by Object under Article 101 TFEU' (n 14), 578f.

18 See Jones, Sufrin, and Dunne (n 5), 219f.; Bailey, Bellamy \& Child (n 7), 169; Guidelines on the application of Article 81(3) of the Treaty [2004] OJ C 101/97 (henceforth Article 101(3) Guidelines), para 22; Luc Peeperkorn, 'Defining "By Object" restrictions' [2015] 3 Concurrences 40, 49; Ola Kolstad, 'Object contra effect in Swedish and European competition law' (Uppdragsforskningsrapport 2009:3, Konkurrensverket: Swedish Competition Authority 2009), 13; Bailey, 'Restrictions of Competition by Object under Article 101 TFEU' (n 14), 578f.

${ }^{19}$ See Whish and Bailey (n 10), 123; Joined cases 29/83 and 30/83 CRAM v Commission ECLI:EU:C:1984:130, paras 25-26.

${ }^{20}$ See C-228/18 Budapest Bank (n 6), para 37.

${ }^{21}$ See ibid, para 37; see also eg Bailey, Bellamy \& Child (n 7), 165; C-209/07 BIDS (n 6), para 15; C-8/08 T-

Mobile (n 7), para 28; C-307/18 Generics (n 11), para 67.

22 See C-228/18 Budapest Bank (n 6), para 35.
} 
behaviour $[\ldots]$ may be considered so likely to have negative effects $[\ldots]$ that it may be considered redundant [...] to prove that it has actual effects on the market." 23 The court explained that we can know this because "[e]xperience shows" 24 that so is the case.

One can discern a two-step procedure from the court's reasoning. First, certain types of collusion reveal, based on experience, a sufficient degree of harm to competition (henceforth, called 'by object types of collusion'). Secondly, the contested agreement in a particular case must be possible to subsume under one such type of collusion. ${ }^{25}$ In hindsight, this appears not to be a new approach. It has been tenably proposed that it was adopted already in case C-67/13 P CB. ${ }^{26}$ The traits of the approach can furthermore be traced back to at least Case 19/77 Miller, where the court held that "by its very nature, a clause prohibiting exports constitutes a restriction on competition", ${ }^{27}$

Still, these findings leave three questions unanswered. Firstly, what are by object types of collusion? Secondly, what is required for an agreement to be subsumed under a by object type of collusion? Thirdly, how is the burden of proof divided between the responsible competition authority and the defendant, respectively? In the following, these questions are explored in turn.

\section{BY OBJECT TYPES OF COLLUSION}

An agreement must be subsumed under a by object type of collusion to be restrictive by object. The subsumption of an agreement under a by object type of collusion is possible if "[e]xperience shows that such behaviour leads to" 28 sufficient harm with sufficient likeliness. ${ }^{29}$ Two questions arise. Firstly, when is experience sufficient for allowing clustering of certain agreements into a 'type' of collusion that is considered sufficiently likely to be sufficiently harmful? Secondly, what do sufficient harmfulness and sufficient likeliness mean?

As to the first question, it appears that the court has established four guiding conditions for the sufficiency of experience. For an agreement to be restrictive by object, the experience must be "sufficiently reliable and robust" 30 and "sufficiently general and consistent" ${ }^{31}$ Only experience meeting those conditions may show that a type of collusion is sufficiently likely to cause sufficient harm as to be considered anti-competitive by its very nature. $^{32}$

About the meaning of those four concepts, the following can be adduced. The requirement of 'reliable' and 'robust' experience appears to be related to whether the experience is substantial enough for doubtlessly considering a type of collusion to be

\footnotetext{
23 See ibid, para 36.

24 See ibid, para 36; comp Bailey, Bellamy \& Child (n 7), 168; Article 101(3) Guidelines (n 18), para 21.

${ }^{25}$ See Peeperkorn (n 18), 50; Case C-611/16 P Xellia Pharmaceuticals (n 12), para 121; comp Kolstad (n 18), 6ff. and $19 \mathrm{f}$.

${ }^{26}$ See Peeperkorn (n 18), 43.

${ }^{27}$ See Case 19/77 Miller International Schallplatten GmbH v Commission ECLI:EU:C:1978:19, para 7.

${ }^{28}$ See C-228/18 Budapest Bank (n 6), para 36 and 54; see also C-286/13 P Dole Food and Dole Fresh Fruit Europe $v$ Commission ECLI:EU:C:2015:184, para 115; C-67/13 P CB (n 11), para 51; Article 101(3) Guidelines (n 18), para 21.

${ }^{29}$ See eg C-286/13 P Dole (n 28), paras 113-115; C-67/13 P CB (n 11), paras 49-51; C-307/18 Generics (n 11), paras 64-67; comp Jones, Sufrin, and Dunne (n 5), 281f.; Ioannidou and Nowag (n 10), 350.

30 See C-228/18 Budapest Bank (n 6), para 76.

31 See ibid, para 79 .

32 See ibid, paras 76 and 79 with 35 and 36; see for that effect C-67/13 CB (n 11).
} 
sufficiently likely to entail sufficient harm. ${ }^{33}$ As for generality and consistency, the implication is obscure since the court has not defined those concepts. However, the concepts could tenably be understood as subordinated to the requirement of reliable and robust experience. ${ }^{34}$ As Advocate General Bobek has expressed the matter, the question is whether the experience is sufficiently widespread and consistent for classifying the relevant type of collusion as "generally harmful to competition". 35

As for the meaning of 'general', the concept could semantically be understood as requiring sufficient experience for the inductive creation of a generalised rule. ${ }^{36}$ The experience that certain agreements sufficiently likely entail sufficient harm, ${ }^{37}$ should allow for clustering of those agreements into a 'type' of collusion based on discovered commonalities (common denominators). ${ }^{38}$ Two important points should be made in this regard. Firstly, relevant experience appears not to be confined to previous case-law but may include also other experiences such as economic theory. ${ }^{39}$ Secondly, a type of collusion is not necessarily confined to a "specific category of an agreement in a particular sector"; ${ }^{40}$ instead, Advocate General Kokott has described the experience-based rule in the following way:

[C]ertain forms of collusion, such as the exclusion of competitors from the market, are, in general and in view of the experience gained, so likely to have negative effects on competition that it is not necessary to demonstrate that they had such effects in the particular case at hand. ${ }^{41}$

Consequently, a novel form of agreement can be found restrictive by object, if it features the common denominators of a (generally defined) by object type of collusion. ${ }^{42}$

As for the meaning of 'consistency', in its turn, it could semantically be understood as concerning whether the overall result of the clustered collusions renders the type of collusion

\footnotetext{
${ }_{33}$ See C-228/18 Budapest Bank (n 6), para 76 with the presumption of innocence; see on the presumption of innocence including the principle that any doubt should benefit the defendant T-442/08 CIS ACv Commission ECLI:EU:T:2013:188, paras 92-93; Jones, Sufrin, and Dunne (n 5), 140; Case C-89/11 P E.ON Energie v Commission ECLI:EU:C:2012:738, para 72; C-593/18 P ABB v Commission ECLI:EU:C:2019:1027, para 100; see also about similarities with criminal law Jones, Sufrin, and Dunne (n 5), 882ff.; C-272/09 P KME Germany and Others v Commission ECLI:EU:C:2011:810, opinion of AG Sharpston ECLI:EU:C:2011:63, para 67; C501/11 P Schindler Holding and Others v Commission ECLI:EU:C:2013:522, para 33.

${ }^{34}$ See for indication of such subordination C-228/18 Budapest Bank (n 6), opinion of AG Bobek ECLI:EU:C:2019:678, paras 70-71.

35 See C-228/18 Budapest Bank, opinion of AG Bobek (n 34), para 63, seemingly followed by the court in C228/18 Budapest Bank (n 6), para 77; see also Peeperkorn (n 18), 44.

36 See for the definition of 'general' Cambridge dictionary - "involving or relating to most or all people, things, or places, especially when these are considered as a unit" <

$<$ https://dictionary.cambridge.org/dictionary/english/general>, visited 2021-04-06; Merriam-Webster > "involving, relating to, or applicable to every member of a class, kind, or group" < https://www.merriamwebster.com/dictionary/general>, visited 2021-04-06.

${ }^{37}$ Comp C-591/16 P Lundbeck (n 11), opinion of AG Kokott ECLI:EU:C:2020:428, para 156.

38 See on common denominators C-307/18 Generics (n 11), para 90-93; comp. C-611/16 P Xellia

Pharmaceuticals (n 12), paras 96-99 and 121 - clarifying that there are certain categories of agreements, based on certain traits, being harmful to competition.

${ }^{39}$ See Case C-67/13 P CB, opinion of AG Wahl (n 14), para 56 and 79; Stina Tannenbaum, 'The concept of the restriction of competition 'by object' under article 101(1)' (2015) 22(1) MJECL 138, 143f.; Peeperkorn (n 18), 44f.; comp. C-591/16 P Lundbeck (n 11), para 130.

40 See C-591/16 P Lundbeck, opinion of AG Kokott (n 37), para 156.

${ }^{41}$ See C-591/16 P Lundbeck, opinion of AG Kokott (n 37), para 156 (emphasis added).

${ }^{42}$ See T-472/13 Lundbeck v Commission [2016] ECLI:EU:T:2016:449, paras 438 and 774, confirmed on appeal in C-591/16 P Lundbeck (n 11), para 130; comp Peeperkorn (n 18), $44 \mathrm{f}$.
} 
sufficiently likely to cause sufficient harm. ${ }^{43}$ Experience that a type of collusion merely sporadically entails sufficient harm could barely be considered to reliably and robustly support the conclusion that that collusion is sufficiently likely harmful. ${ }^{44}$

In summary, it could be understood that experience is sufficiently reliable and robust for classifying an agreement as a by object type of collusion if the experience is sufficiently general and consistent. Experience is sufficiently general and consistent if common denominators can be discerned for agreements that are sufficiently likely to cause sufficient harm to competition.

As to the second question - the meaning of sufficient harmfulness and sufficient likeliness - a general description of by object types of collusions that has figured in case-law is that those types of collusion "reveal a sufficient degree of harm to competition to be regarded as being restrictions by object". 45 This is because they are "so likely to have negative effects" ${ }^{\text {"46 }}$ as to render consideration to their actual effects redundant. ${ }^{47}$ As discerned above, sufficient likeliness and sufficient harm are determined based on experience. In the following part of this section, I examine, first, the required degree of harm and, subsequently, the required likeliness.

The substance of a sufficient degree of harm is not apparent, but two constituent elements are tenable. As for the first element, it has been proposed in the legal doctrine that a certain type of collusion is 'sufficiently harmful' only if experience shows that it entails not only negative effects on competition but net negative effects. The latter implies that the relevant type of collusion should be restrictive under Article 101(1) as well as not justified under Article 101(3) TFEU. ${ }^{48}$ This understanding is tenable as endorsing consistency. Namely, caselaw describes by object types of collusion as entailing a fall in competitive benefits, to the detriment of consumers, ${ }^{49}$ which is ultimately the case only absent fully counteracting efficiency gains. ${ }^{50}$ Furthermore, the understanding explains and legitimises the perception that restrictions by object are only unlikely (albeit not impossibly) justified under Article 101(3) TFEU. ${ }^{51}$ Lastly, it harmonises with the restrictive interpretation of restrictions by object, ${ }^{52}$ thus reducing the risk of false positives. ${ }^{53}$

\footnotetext{
${ }^{43}$ See for the definition of 'consistent' Cambridge dictionary - "always behaving or happening in a similar, especially positive, way" < https://dictionary.cambridge.org/dictionary/english/consistent $>$, visited 202104-06>; Merriam-Webster - "marked by harmony, regularity, or steady continuity" < https://www.merriamwebster.com/dictionary/consistent $>$, visited 2021-04-06.

${ }^{44}$ Comp C-228/18 Budapest Bank (n 6), para 79; Mark Friend, 'Restrictions by Object Under EU Competition Law' (2020) 79(3) CLJ 423, $426 f$.

45 See C-228/18 Budapest Bank (n 6), para 35.

46 See ibid, para 36.

${ }^{47}$ See eg C-286/13 P Dole (n 28), paras 113-115; C-67/13 P CB (n 11), paras 49-51; C-307/18 Generics Generics (n 11), paras 64-67; comp Jones, Sufrin, and Dunne (n 5), 281f.; Ioannidou and Nowag (n 10), 350. ${ }^{48}$ See Peeperkorn (n 18), 41f. and 49; Pablo Ibáñez Colomo and Alfonso Lamadrid, 'On the Notion of Restriction of Competition: What We Know and What We Don't Know We Know' (SSRN 2016) <https://papers.ssrn.com/sol3/papers.cfm?abstract_id=2849831> accessed 27 March 2021, 21; comp C228/18 Budapest Bank (n 6), paras 35-36; C-228/18 Budapest Bank, opinion of AG Bobek (n 34), para 40. 49 See C-228/18 Budapest Bank (n 6), para 36; C-57/13 P CB (n 11), para 51.

${ }^{50}$ Comp Article 101(3) Guidelines (n 18), para 85; Jones, Sufrin, and Dunne (n 5), 269.

51 See Article 101(3) Guidelines (n 18), para 46; Guidance on restrictions of competition "by object" for the purpose of defining which agreements may benefit from the De Minimis Notice, SWD(2014) 198 final (henceforth By Object Guidance), 4; Bailey, 'Restrictions of Competition by Object under Article 101 TFEU' (n 14), 593ff.; Amato (n 9), 40 and 46.

52 See C-67/13 P CB (n 11), para 58; C-307/18 Generics (n 11), para 68; C-228/18 Budapest Bank (n 6), para 54.

53 Comp Peeperkorn (n 18), 49.
} 
As a second and additional element, only collusion having, by experience, an appreciable effect on competition appears to be 'sufficiently harmful'. Namely, sufficient is when something amounts to at least what is required; as settled since early days, agreements with merely an "insignificant effect" 54 on competition fall outside the scope of Article 101(1) TFEU. This condition has later been titled a requirement of appreciable effect on competition. ${ }^{55}$ Naturally, by object types of collusion should thus entail at least an appreciable restriction of competition. Not the least, a condition of appreciable restriction would explain the notorious expression in case C-226/11 Expedia - the restriction caused by an agreement classified as a restriction by object is appreciable "by its nature". ${ }^{56}$

Leaving the requirement of sufficient harm, such harm must additionally be sufficiently likely. Tenably understood, the latter requires experience to render negative effects so likely that there can be no reasonable doubt as to their realisation. ${ }^{57} \mathrm{~A}$ high requirement of likeliness would be consistent with both the restrictive interpretation of restrictions by object, ${ }^{58}$ and the principle within competition law that any doubt must benefit the defendant. ${ }^{59}$ Consonantly, the court has proclaimed that the likeliness shall render an assessment of effects superfluous; in other words, "it may be considered redundant [...] to prove that [the disputed agreement] has actual effects on the market". ${ }^{60}$

Importantly, however, the requirement of likeliness relates only to the effects of the relevant type of collusion in general (by experience) and not of an individual disputed agreement. ${ }^{61}$ Adopting a likeliness requirement in casu would amount to an alignment of restrictions by object and restrictions by effect since the latter is conditioned upon actual or potential (likely) anti-competitive effects in casu. ${ }^{62}$

To sum up, seemingly only types of collusion that by experience are sufficiently likely to entail sufficient harm to competition are by object types of collusion. A palatable interpretation is that a sufficient degree of harm requires the relevant type of collusion to be, by experience, sufficiently likely to entail both appreciable and net negative effects. This harm is sufficient likely if experience precludes any reasonable doubt as to the realisation of the restrictive effects of the type of collusion in general.

\footnotetext{
${ }^{54}$ Case 5/69 Voelk v Vervaecke ECLI:EU:C:1969:35.

${ }^{55}$ See Jones, Sufrin, and Dunne (n 5), 196; Jonathan Faull and others, 'Article 101' in Jonathan Faull and Ali Nikpay (eds), Faull \& Nikpay: the EU law of competition (3rd edn, Oxford University Press 2014), 243; Bailey, 'Restrictions of Competition by Object under Article 101 TFEU' (n 14), $590 \mathrm{ff}$.

56 See C-226/11 Expedia ECLI:EU:C:2012:795, para 37; comp Bailey, Bellamy \& Child, 171 (n 7); Faull and others (n 55), 246f.; Notice on agreements of minor importance which do not appreciably restrict competition under Article 101(1) of the Treaty on the Functioning of the European Union (De Minimis Notice) [2014] OJ C 291/1 (henceforth De Minimis Notice), paras 2 and 13.

${ }^{57}$ Comp Wahlin (n 14), 340.

${ }^{58}$ See C-67/13 P CB (n 11), para 58; C-307/18 Generics (n 11), para 68; C-228/18 Budapest Bank (n 6), para 54.

${ }^{59}$ See T-442/08 CISAC (n 33), paras 92-93; Jones, Sufrin and Dunne (n 5), 140; C-89/11 P E.ON (n 33), para 117.

${ }^{60}$ See C-228/18 Budapest Bank (n 6), para 36; C-67/13 P CB (n 11), para 51; C-345/14 Maxima Latvija (n 11), para 19.

${ }_{61}$ See C-67/13 P CB (n 11), para 51; C-228/18 Budapest Bank (n 6), para 36; C-307/18 Generics (n 11), opinion of AG Kokott ECLI:EU:C:2020:28, para 159.

${ }^{2}$ See Jones, Sufrin, and Dunne (n 5), 240; Ibáñez Colomo and Lamadrid (n 48), 35; T-347/94 Mayr-Melnhof Kartongesellschaft v Commission ECLI:EU:T:1998:101, para 136; Case C-67/13 P CB (n 11), paras 82-83; Faull and others (n 55), 284ff.; Bailey, Bellamy \& Child (n 7), 176f.; Article 101(3) Guidelines (n 18), para 24.
} 


\section{SUBSUMPTION UNDER A BY OBJECT TYPE OF COLLUSION}

As discerned above, restrictions by object are fundamentally about subsuming the disputed agreement under (in other words, match it with) a by object type of collusion, based on experience. In establishing a restriction by object, one must have regard to three factors: the agreement's content, its objectives, and its economic and legal context. ${ }^{63}$ Thus, the same three factors should form constituents of the experience of by object types of collusion. ${ }^{64}$ Yet, while content and objectives relatively clearly are necessary for the matching procedure, ${ }^{65}$ there is less clarity in the role of context.

Namely, it has been proposed that the context analysis, rather than being part of the requirement of matching with experience, establishes a second requirement: a limited effects analysis, capable of rebutting an experience-based conclusion drawn from the content and objectives. ${ }^{66}$ The origins are most clearly derived from case C-32/11 Allianz. Hungária, based on case C-8/08 T-Mobile. In Allianz Hungária, the court proclaimed the following:

[1] $\mathrm{t}$ is sufficient that [an agreement] has the potential to have a negative impact on competition, that is to say, that it be capable in an individual case of resulting in the prevention, restriction or distortion of competition within the internal market. ${ }^{67}$

On this backdrop, it has been proposed that the context analysis includes consideration to effects. Thus, the distinction between a context and effects analysis would be "more one of degree than of kind". ${ }^{68}$

In contrast to those proposals, the subsequent parts of section 4 of this article present an explanation of restrictions by object as not including any assessment of a disputed agreement's effects. The explanation is closely connected to the judgements of the CJ which, as I show in the following, can be structured in a two-step approach. The first step is to establish a match between the disputed agreement and the common denominators of a by object type of collusion. The second step is to assess whether the disputed agreement despite a match in the first step - features contextual anomalies, preventing subsumption of the agreement under a by object type of collusion.

\footnotetext{
${ }^{63}$ See Peeperkorn (n 18), 50; comp C-67/13 P CB (n 11), para 53.

${ }^{64}$ Comp Tannenbaum (n 39), 142ff. and 148 - relating context to experience and distinguish it from effects; Peeperkorn (n 18), 45ff. and 50 - recognising context as a factor for matching with experience; See for example on content, objectives, and context in relation to experience C-307/18 Generics, opinion of AG Kokott (n 61), para 159 - "market sharing between competitors"; C-67/13 P CB (n 18), para 51 - "horizontal price-fixing by cartels".

${ }^{65}$ See Peeperkorn (n 18), 46 - "While the wording of every agreement and its clauses may be different, an investigation of its content and objectives will usually make clear whether the agreement in question, for instance, is a price fixing agreement."; Friend (n 44), 425.

${ }^{66}$ See in general eg Jones, Sufrin, and Dunne (n 5), 236; C-228/18 Budapest Bank, opinion of AG Bobek (n 34), paras 49-50; see about proposals of a quick effects analysis Ioannidou and Nowag (n 11), $361 \mathrm{ff}$.; comp Bailey 'Restrictions of Competition by Object under Article 101 TFEU' (n 14), 585ff.; see about proposals of an incapability defence C-228/18 Budapest Bank, opinion of AG Bobek (n 34), paras 48-49; Okeoghene Odudu, 'Restriction of Competition by Object - What's the Beef?' (2009) 8(1) Comp Law 11, 15; Faull and others (n 55), 242.

${ }^{67}$ See C-32/11 Allianz Hungária Biztositó and Others ECLI:EU:C:2013:160, para 38 (emphasis added); comp C8/08 T-Mobile (n 7), para 31.

${ }^{68}$ See C-228/18 Budapest Bank, opinion of AG Bobek (n 34), para 50; comp Ioannidou and Nowag (n 10), 363; Faull and others (n 55), 242.
} 
Step 1 - Match between the disputed agreement and common denominators of a by object type of collusion considering content, objectives, and context, but not effects

Proposing a link between context and effects indubitably appears inappropriate. Firstly, analysing the context (an observable setting) is an essential element of any restriction - by object as well as by effect - since no restrictions can occur in an economic or legal vacuum. ${ }^{69}$ Thus, inevitably, our experience of restrictive collusions includes not only content and objectives, but also context. ${ }^{70}$ For instance, by object types of collusion may vary depending on the competitive relation - horizontal or otherwise - between the colluding parties. ${ }^{71}$ Secondly, an assessment of context (the observable setting) is separate from an assessment of effects (the result of a particular cause). ${ }^{72}$ The latter requires both an observation of the context of the agreement, and a comparison with the context in a counterfactual scenario; the differences discerned are the effects. ${ }^{73}$ In other words, while a restriction by object requires consideration to "the economic and legal context of which [the disputed agreement] forms a part", 74 a restriction by effect requires, additionally, that "competition should be assessed within the actual context in which it would occur in the absence of the agreement in dispute". ${ }^{75}$

The presented division between consideration to context and effects is apparent from case C-591/16 P Lundbeck. In this case, the CJ held as follows:

$[\mathrm{U}]$ nless the clear distinction between the concept of 'restriction by object' and the concept of 'restriction by effect' $[\ldots]$ is to be held not to exist, an examination of the 'counterfactual scenario', the purpose of which is to make apparent the effects of a given concerted practice, cannot be required in order to characterise a concerted practice as a 'restriction by object'. ${ }^{76}$

Aligned with this expression, case-law has settled that "there is no need to take account of the concrete effects of an agreement once it appears that it has as its object the prevention,

\footnotetext{
${ }^{69}$ See Bailey, Bellamy \& Child (n 7), 153; see about restriction by object C-209/07 BIDS (n 6), para 16; C31/11 Allianz. Hungária (n 67), para 36; C-345/14 Maxima Latvija (n 11), para 16; C-591/16 P Lundbeck (n 11), para 112; see about restriction by effects C-345/14 Maxima Latvija (n 11), para 26; C-234/89 Delimitis v Henninger Bräu ECLI:EU:C:1991:91, para 14; Case 23/67 Brasserie De Haecht v Wilkin Janssen ECLI:EU:C:1967:54, 415.

${ }^{70}$ Comp Peeperkorn (n 18), 45 and 50; C-611/16 P Xellia Pharmacenticals (n 12), paras 116, 117, 120, and 121; C-601/16 P Arrow (n 12), para 87; C-67/13 P CB (n 11), para 78; Tannenbaum (n 39), 143f. and 148.

${ }^{71}$ See Peeperkorn, 46; By Object guidance (n 51), 4; C-228/18 Budapest bank (n 6), para 36 - giving the example of "horizontal price-fixing by cartels" as a by object type of collusion.

72 See C-611/16 P Xellia Pharmaceuticals (n 12), paras. 116-117; C-601/16 P Arrow (n 12), paras 85-87; see about an early conclusion on this matter Tannenbaum (n 39), 148.

73 see Bailey, Bellamy \& Child (n 7), 158f.; C-382/12 P MasterCard and Others v Commission

ECLI:EU:C:2014:2201, paras 164-169; Horizontal Co-operation guidelines, para 29; Vertical Guidelines, para 97.

${ }^{74}$ See C-228/18 Budapest Bank (n 7), para 51; see also C-67/13 P CB (n 11), para 53; C-591/16 P Lundbeck (n 11), para 112 .

75 See C-307/18 Generics (n 11), para 118 (emphasis added); see also C-228/18 Budapest Bank (n 6), para 55; Case 42/84 Remia BV and others v Commission ECLI:EU:C:1985:327, para 18; C-382/12 P MasterCard (n 73), paras $164-169$.

${ }_{76}$ See C-591/16 P Lundbeck (n 11), para 140.
} 
restriction or distortion of competition." ${ }^{\prime 77}$ In conclusion, and contrary to what has been proposed as a matter of legal consensus, ${ }^{78}$ the finding of a restriction by object does not necessitate a counterfactual assessment, and (consequently) not an assessment of effects. ${ }^{79}$

Since context and effect are distinct concepts, consideration to the prior naturally does not justify consideration to the latter. Consequently, only one requirement for establishing a restriction of competition by object appears to exist; it suffices that disputed agreements "can in fact be classified as "restrictions by object". ${ }^{80}$ An agreement can be classified as a restriction by object only if it "reveals a sufficient degree of harm to competition". ${ }^{81}$ From experience, by object types of collusion reveal a sufficient degree of harm to competition. ${ }^{82}$ Thus, an agreement can be classified as restrictive by object only if the experience of a by object type of collusion is sufficiently robust and reliable for being applied to that agreement, having regard to its content, objectives, and context. ${ }^{83}$ This assessment is limited to considering the possibility to rely on the experience of by object types of collusion; as the CJ held in Lundbeck, the Commission could declare an agreement restrictive by object solely based on its content, objectives, and context but "was not required, however, to examine the effects thereof." ${ }^{84}$ Phrased differently, the scope of the assessment appears limited to whether the traits of the disputed agreement correlates (matches) with the common denominators of a by object type of collusion.

I will now concretise these findings by an example based on case C-307/18 Generics. This case concerned GlaxoSmithKline ("GSK") that produced a medicine to which it held related patents. Several (potential) competitors contemplated entering the relevant market with generic medicines, which led GSK to initiate genuine patent infringement proceedings ${ }^{85}$ The proceedings were concluded by settlement agreements. Through these agreements, the alleged patent infringers undertook, in return for substantial payments by GSK, to neither enter the relevant market nor challenge the patents of GSK. Simultaneously, the agreements included provisions allowing for limited distribution of generics by the alleged patent infringers. ${ }^{86}$

The CJ in Generics described the relevant experience for establishing that a dispute settlement agreement is harmful by nature. It held that such agreements are in principle not

\footnotetext{
77 See Joined cases 56 and 58/64 Consten and Grundig $v$ Commission of the EEC ECLI:EU:C:1966:41, 342; see also C-209/07 BIDS (n 6), paras 16 and 18; C-228/18 Budapest Bank (n 6), paras 35, 34 and 54; C-307/18 Generics (n 11), para 64; C-591/16 P Lundbeck (n 11), para 141; C-68/12 Slovenská sporitelña ECLI:EU:C:2013:71, para 17; C-601/16 P Arrow (n 12), para 84-87; C-440/11 P Commission v Stichting Administratiek antoor Portielje ECLI:EU:C:2013:514; Bailey, Bellamy \& Child (n 7), 170.

78 See about proposed legal consensus Ibáñez Colomo and Lamadrid (n 48), 4, 8ff., and 44; comp Article 101(3) Guidelines (n 18), para 17.

${ }^{79}$ Comp C-382/12 P MasterCard (n 73), paras 186-192; n 75 and text thereto.

${ }^{80} \mathrm{C}-307 / 67$ Generics (n 11), para 65.

81 See C-228/18 Budapest Bank (n 6), para 51.

82 See ibid, paras 35-36.

${ }^{83}$ See, to that effect, C-228/18 Budapest Bank (n 6); C-67/13 CB (n 11); Comp Peeperkorn (n 18), 45f.; C591/16 P Lundbeck (n 11), para 112; C-307/18 Generics (n 11), paras 64-67 and 103; C-345/14 Maxima Latvija (n 11), paras 16-20; C-307/18 Generics, opinion of AG Kokott (n 61), paras 100-101. 84 See C-591/16 P Lundbeck (n 11), para 141; comp C-601/16 P Arrow (n 12), para 87; C-382/12 P MasterCard (n 73), para 186 - the court concluded that the GC had not adopted a restriction by object because it had based its decision on effects.

${ }^{85}$ See about genuine disputes C-307/18 Generics (n 11), para 76.

86 See C-307/18 Generics (n 11), para 75.
} 
problematic. ${ }^{87}$ However, a settlement agreement was considered restrictive by object if the value transferred by it "cannot have any explanation other than the commercial interest of both the holder of the patent and the party allegedly infringing the patent not to engage in competition on the merits". ${ }^{88}$ The court outlined three conditions for making the latter finding. Firstly, there should be a settlement agreement between a patent holder and a (potential) competitor, where the latter undertakes not to enter the relevant market. ${ }^{89}$ Secondly, the value transferred to the alleged infringers should not be justified by "any quid pro quo or waivers" ${ }^{\prime 90}$ by the patent holder. Thirdly, the value transferred should appear sufficiently beneficial as to, irrespective of a counterfactual scenario, incentivise the alleged infringer to abstain from entering the market. ${ }^{91}$

The conditions outlined could be understood as the common denominators of the relevant by object type of collusion. The common denominators are not as clearly outlined for all by object types of collusion. For instance, concerning horizontal price-fixing, the conditions have been expressed in different terms, which, however, all boils down to (firstly) an agreement between competitors, that (secondly) aims at directly or indirectly removing uncertainty regarding future pricing. ${ }^{92}$ If the common denominators are met by an agreement, it "must, in principle, be characterised as a 'restriction by object". ${ }^{93}$ Contrastingly, if not met, a restriction by object appears not possible to establish; the agreement cannot, in that case, be classified as a by object type of collusion. ${ }^{94}$

The understanding of restrictions by object which is presented in this section appears by no means revolutionary. Advocate General Kokott has already shed light in this direction. In her opinion in Generics, she explained that contextual elements, firstly, are necessary for classifying an agreement as a by object type of collusion ${ }^{95}$ and, secondly, may cast doubt on that classification ${ }^{96}$ without effects having to be considered. ${ }^{97}$ Furthermore, in her opinion in T-Mobile, she framed the requirement for finding a restriction by object in the following way:

$[1] \mathrm{t}$ is sufficient that a [disputed agreement] has the potential - on the basis of existing experience - to produce a negative impact on competition. In other words, the [disputed agreement] must simply be capable in an individual case, that is, having regard to the specific legal and economic context, of resulting

\footnotetext{
${ }^{87}$ See ibid, para $85-86$.

88 See ibid, para 87.

${ }^{89}$ See ibid, para 90.

${ }^{90}$ See ibid, para 92.

${ }^{91}$ See ibid, para 93; comp C-591/16 P Lundbeck (n 11), para 140.

92 See eg C-286/13 P Dole (n 28), paras 121, 122, 124 and 134; C-8/08 T-Mobile (n 7), para 43; By Object

Guidance (n 51), 6; comp Article 101(1)(a) TFEU; C-228/18 Budapest Bank (n 6), para 36.

93 See C-307/18 Generics (n 11), para 95 (emphasis added).

${ }^{94}$ Comp ibid, paras 85-87; n 36 - 42 and text thereto; See about agreement not meeting the common denominators C-345/14 Maxima Latvija (n 11), para 21.

95 See C-307/18 Generics, opinion of AG Kokott (n 61), paras 158-159.

96 See ibid, paras 165, 166, and 180.

${ }^{97}$ See ibid, para 164.
} 
in the prevention, restriction or distortion of competition within the common market. ${ }^{98}$

This expression does illuminate the nearly identical expressions about capability in T-Mobile and Allianz Hungária; ${ }^{99}$ particularly considering that the CJ, in T-Mobile, adopted the approach "as pointed out by the Advocate General at point 46 of her Opinion". ${ }^{100}$ Thus, maybe it has never been about effects - maybe it has always been about matching with experience. That understanding is attractive considering the quite consequent assurance by the $\mathrm{CJ}$ that restrictions by object are separated from effects. ${ }^{101}$

Step 2 - Agreement at dispute does not present any contextual anomalies that bring doubt to reliance on experience

Even if the common denominators are met, an agreement is only "in principle" 102 possible to subsume under a by object type of collusion. All the relevant factors of the individual case must be assessed; contextual factors in addition to the common denominators (henceforth called 'contextual anomalies') may exist which cast doubt on the reliability of experience in casu. ${ }^{103}$ This is not strictly a question of rebuttal, since a restriction by object is not a presumption but rather an inchoate offence. ${ }^{104}$ Once a restriction by object is established, the agreement is prohibited unless objectively justified under Article 101(1) TFEU or justified under Article 101(3) TFEU. ${ }^{105}$ Instead of rebutting a finding of a restriction by object, the question appears to concern only whether the experience is sufficiently reliable and robust for fulfilling the standard of proof for finding that the disputed agreement is a by object type of collusion and thus restrictive by object. ${ }^{106}$ In the following, I will explain, firstly, that experience can tell whether contextual anomalies are relevant or not and, secondly, that effects in casu are still not necessary to assess.

Firstly, in Generics the CJ dismissed three factors as not precluding reliance on experience as to the restrictive object. In the first instance, the court held as settled case-law that a patent "does not permit its holder to enter into contracts that are contrary to Article 101 TFEU". ${ }^{107}$ In the second instance, the court dismissed any relevance of uncertainty as to the outcome of the court proceedings, and thus to the patent's strength - such uncertainty is, as settled, part of the competitive process. ${ }^{108}$ In the last instance, the court held that alleged

\footnotetext{
${ }^{98}$ See C-8/08 T-Mobile, opinion of AG Kokott (n 15), para 46 (emphasis added); see also Ibáñez Colomo and Lamadrid (n 48), 34f.

99 See C-8/08 T-Mobile (n 7), para 31; C-32/11 Allianz Hungária (n 67), para 38 and text thereto.

100 See C-8/08 T-Mobile (n 7), para 31.

101 See n 77-79.

102 See C-307/18 Generic (n 11), para 65.

103 See C-307/18 Generics, opinion of AG Kokott (n 61), paras 158-161; Comp C-307/18 Generics (n 11), para 67; C 601/16 P Arrow (n 12), para 87.

${ }^{104}$ See eg Bailey, 'Restrictions of Competition by Object under Article 101 TFEU' (n 14), 561ff.; C-8/08 T-

Mobile, opinion of AG Kokott (n 14), para 47; comp C-8/08 T-Mobile (n 7), para 31; Bailey, Bellamy \& Child (n 7), $170 \mathrm{f}$.

${ }^{105}$ See eg C-307/18 Generics, opinion of AG Kokott (n 61), para 162 and 147-156; Bailey, 'Restrictions of Competition by Object under Article 101 TFEU' (n 14), 579ff. and 593ff.; By Object Guidance (n 51), 4. 106 See C-307/18 Generics, opinion of AG Kokott (n 61), para 161 with para 162; C-307/18 Generics (n 11), para 107 with paras 67 and 111.

107 See C-307/18 Generics (n 11), para 97; comp about Article 102 TFEU Case T-201/04 Microsoft v Commission [2007] ECLI:EU:T:2007:289, para 690.

108 See C-307/18 Generics (n 11), para 100 with para 81.
} 
pro-competitive effects cannot preclude a restriction by object unless the defendant demonstrates ${ }^{109}$ that those effects are relevant, ${ }^{110}$ specifically related to the agreement concerned," and "sufficiently significant, so that they justify a reasonable doubt as to whether the [agreement] caused a sufficient degree of harm to competition, and, therefore, as to its anticompetitive object." 112 Consequently, experience can answer what contextual factors are irrelevant and, assumptively, also which are relevant. ${ }^{113}$

Secondly, the CJ in Generics appears to have considered that effects in casu can rebut a finding of a restriction by object. In the following, I will explain three untenable interpretations of the judgment. Subsequently, one more attractive interpretation is explained, which does not recognise any role of effects in casu.

A first interpretation would be that a restriction by object is a presumption that can be rebutted if the undertakings concerned prove that the disputed agreement is plausibly net pro-competitive. ${ }^{114}$ If an agreement is proven to be net pro-competitive, there is either no restriction at all or a restriction that is counterweighed by positive effects. Rebutting a restriction by object in the latter scenario would bring a rule of reason to the assessment of restrictions by object. That order would both blur the distinction between Article 101(1) and 101(3) TFEU ${ }^{115}$ and contradict expressions in case-law that there exists no rule of reason under Article 101(1). ${ }^{116}$ Factors other than those calling in question the existence of a restriction should be considered only under Article 101(3). ${ }^{117}$ Consequently, the idea appears too broad to be correct.

A second interpretation would be that the court considered the likelihood of certain effects in casu. This is untenable. Requiring sufficient certainty as to the restrictive effects in casu would undermine the established division between restrictions by object and effect; ${ }^{118}$ one cannot overlook the CJ's statements that an assessment of restriction by object, including consideration to context, "does not imply an assessment of the anticompetitive effects" " of the disputed agreement.

\footnotetext{
${ }^{109}$ See ibid, para 105 with para 103.

110 See ibid, para 105.

111 See ibid, para 105.

112 See ibid, para 107.

${ }^{113}$ See about contextual factors being relevant for instance specialisation agreements fixing prices for joint distribution to immediate customers Commission Regulation (EU) No 1218/2010 of 14 December 2010 on the application of Article 101(3) of the Treaty on the Functioning of the European Union to certain categories of specialisation agreements, Article 4(a); By Object Guidance (n 51), 7.

114 See Ibáñez Colomo and Lamadrid (n 48), 24.

115 See about Article 101(3) TFEU requiring net-positive effects Article 101(3) Guidelines (n 18), para 85; Jones, Sufrin, and Dunne (n 5), 269.

116 See C-307/18 Generics (n 11), para 104; C-307/18 Generics, opinion of AG Kokott (n 61), para 148; Case T208/13 Portugal Telecom v Commission ECLI:EU:T:2016:368, para 102; comp C-209/07 BIDS (n 6), opinion of AG Trstenjak ECLI:EU:C:2008:467, para. 55-58; see for the possibility of application of Article 101(3) to restrictions by object Wahlin (n 14), 330f.; Article 101(3) Guidelines (n 18), paras 20 and 46; Jones, Sufrin, and Dunne (n 5), 262f.; Case T-168/01 GlaxoSmithKline Services v Commission ECLI:EU:T:2006:265, upheld in the relevant regard in joined cases C-501/06, 513/06, 515/06, and C-519/06 P GlaxoSmithKline Services and Others $v$ Commission and Others ECLI:EU:C:2009:610.

117 See C-382/12 P MasterCard (n 73), paras 180-181; Article 101(3) Guidelines (n 18), para 11; Guidelines on the applicability of Article 101 of the Treaty on the Functioning of the European Union to horizontal cooperation agreements [2011] OJ C 11/1 (henceforth Horizontal Co-operation Guidelines), para 20; C-307/18 Generics, opinion of AG Kokott (n 61), para 147; C-209/07 BIDS, opinion of AG Trstenjak (n 116), para 59. 118 See $\mathrm{n}$ 6-8 and 77-79 and text thereto. 119 See C-611/16 P Xellia Pharmaceuticals (n 12), para 117; see also n 69-79 and text thereto.
} 
A third interpretation would be that the court in Generics considered objective justifications under Article 101(1) TFEU, such as the ancillary restraints doctrine. ${ }^{120}$ This is untenable. The court refers to "doubt" as a factor capable of excluding a restriction by object specifically; ${ }^{122}$ however, the doubt referred to does not also exclude a restriction by effects - "where the anticompetitive object of [the disputed agreement] is not established, it is necessary to examine its effects". ${ }^{123}$ Contrastingly, an objective justification excludes any finding of an unlawful restriction, by object as well as by effect. ${ }^{124}$ Thus, a distinction appears between objective justifications and calling a restriction by object into doubt. ${ }^{125}$

Instead of the above interpretations, the question seems to be whether the standard of proof required for establishing a restriction by object is (still) fulfilled ${ }^{126}$ after having had regard to pro-competitive effects (or rather factors alleged to have such effects) invoked by the defendant. ${ }^{127}$ In other words, the court assesses whether contextual anomalies (i.e. deviations from the relevant experience of by object types of collusion) exist, and whether in accounting for those deviations - one can still be (by experience) certain about the common denominators' 'reaction', without assessing the likelihood of certain effects in casu. ${ }^{128}$ To theoretically exemplify by an analogy: imagine a flask containing three substances, the blend of which creates a familiar reaction. Imagine now that, for the first time, a new substance is to be added. Without experience (actual or theoretical) ${ }^{129}$ that renders the new reaction sufficiently certain, actual mixing is required for determining the reaction. Assumptively, the new-gained knowledge can be added to the previously held experience.

In Generics, as for a real-world example, the court set out to assess whether the disputed settlement agreement pursued the object of allowing the parties' to, in their mutual commercial interest, not engage in competition on the merits. Undisputedly, the disputed settlement agreement, in addition to the common denominators, provided for a potentially pro-competitive distribution of generics. However, this anomaly was merely a potential drop in the ocean that, even if the exact effects of the agreements were unknown, could safely be assumed not to cause an unanticipated reaction. ${ }^{130}$ Consequently, a tenable alternative

\footnotetext{
${ }^{120}$ See about objective justifications eg Jones, Sufrin, and Dunne (n 5), 247ff.; Bailey, 'Restrictions of Competition by Object under Article 101 TFEU' (n 14), 580ff.; C-307/18 Generics, opinion of AG Kokott (n 61), paras 149-156; Case C-439/09 Pierre Fabre Dermo-Cosmétique ECLI:EU:C:2011:649, para 39.

121 See C-307/18 Generics (n 11), paras 107 and 110.

122 See ibid, para 103.

123 See ibid, para 66; comp C-307/18 Generics, opinion of AG Kokott (n 61), para 164.

124 See C-307/18 Generics, opinion of AG Kokott (n 61), paras 149-156; Faull and others (n 55), 251; Bailey, Bellamy \& Child (n 7), 162; C-382/12 P MasterCard (n 73), paras 89-90; Jones, Sufrin, and Dunne (n 5), $247 \mathrm{ff}$. 125 See for that effect C-307/18 Generics, opinion of AG Kokott (n 61), paras 149-180; C-67/13 P CB, opinion of AG Wahl (n 14), para 56.

${ }^{126}$ Comp Council regulation (EC) No 1/2003 of 16 December 2002 on the implementation of the rules on competition laid down in Articles 81 and 82 of the Treaty [2003] OJ L 1/1 (hereinafter Reg. 1/2003), Article 2.

127 See C-307/18 Generics, opinion of AG Kokott (n 61), paras 164-165 with C-8/08 T-Mobile, opinion of AG Kokott (n 14), para 46; C-307/18 Generics (n 11), paras 103, 107, and 111 with para 67.

${ }^{128}$ See C-307/18 Generics (n 11), para 107; C-228/18 Budapest Bank (n 6), paras 82-83; C-601/16 Arrow (n 12), para 87 - declaring that the context assessment concerns doubt but "does not also imply an assessment of the anticompetitive effects"; comp for early thoughts in this direction Tannenbaum (n 39), 143ff. and 148.

${ }^{129}$ Comp C-67/13 P CB, opinion of AG Wahl (n 14), para 56.

130 See C-307/18 Generics (n 11), paras 107-110.
} 
understanding of the agreement had not been sufficiently substantiated as to provide for "any explanation other" ${ }^{131}$ than that the agreements pursued an anti-competitive object.

As for a second example, in case $C B$, a similar situation featured, albeit with a successful outcome for the defendant. In $C B$, the $C J$ set out to assess whether the GC wrongly concluded that the disputed agreements "have as their object the restriction of competition $[\ldots]$ in that, essentially, they hinder the competition of new entrants on the [relevant market]." 132 The court pinpointed that "that restrictive object must be established", ${ }^{133}$ and found that, in the present dispute it could not sufficiently be so. ${ }^{134}$ The rationale appears to have been that there existed a contextual anomaly to the relevant experience; ${ }^{135}$ namely, the agreements concerned two interrelated markets. Based on that anomaly, the defendants argued that the agreements pursued the legitimate objectives of creating a balance between the related markets and of combatting so-called free-riding. ${ }^{136}$ The CJ recognised the argument and concluded that it could, in keeping with an experience-based assessment, neither be assumed nor ruled out that the agreement in casu was restrictive on competition; an assessment of effects would be necessary for such a finding. ${ }^{137}$

\section{DIVISION OF BURDEN OF PROOF}

The existence of an anti-competitive object cannot be found in the abstract but only by taking into consideration all the relevant factors of an individual case. ${ }^{138}$ The burden of proof, in this regard, lies on the responsible competition authority ${ }^{139}$ which must establish an anticompetitive object by jointly considering content, objectives, and context with the relevant experience of by object types of collusion. ${ }^{140}$ Context, like content, and objectives, serves an incriminatory function. ${ }^{141}$ However, case-law has settled that the assessment of context may "be limited to what is strictly necessary in order to establish the existence of a restriction of competition by object". ${ }^{142}$ This expression indicates an eased burden on the relevant competition authority but leaves unanswered to what extent context is necessary to consider.

\footnotetext{
131 See ibid, para 87.

132 See C-67/13 P CB (n 11), para 60; comp C-209/07 BIDS (n 6) - this is the case on which the Commission, in $C B$, based its allegations.

133 See C-67/13 P CB (n 11), para 70.

134 See ibid, paras 73-75.

135 See about experience C-67/13 P CB (n 11), para 51; C-67/13 P CB, opinion of AG Wahl (n 14), paras 79 and 56; comp C-209/07 BIDS (n 6) - this was the reference case constituting central experience in $C B$. 136 See C-67/13 P CB (n 11), paras 75-76.

${ }^{137}$ See ibid, paras 80-81, with 51; see C-67/13 P CB, opinion of AG Wahl (n 14), paras 56, 79, and 131.

138 See Bailey, 'Restrictions of Competition by Object under Article 101 TFEU' (n 14), 582f.; Bailey, Bellamy

\& Child (n 7), 153; C-67/13 P CB, opinion of AG Wahl (n 14), paras 40-41; C-551/03 P General Motors ECLI:EU:C:2006:229, para 66; C-307/18 Generics, opinion of AG Kokott (n 61), para 158.

139 See Reg. 1/2003 (n 126), Article 2.

140 See to that effect C-228/18 Budapest Bank (n 6), paras 66-79; comp C-591/16 P Lundbeck (n 11), para 112; Bailey, 'Restrictions of Competition by Object under Article 101 TFEU' (n 14), 582f.; see about necessity of considering content, objectives and context C-228/18 Budapest Bank (n 6), para 51; see also C-67/13 P CB (n 11), para 53; Jones, Sufrin, and Dunne (n 5), 219f.; Faull and others (n 55), 236; Bailey, Bellamy \& Child (n 7), 166; Article 101(3) Guidelines (n 18), para 22.

${ }^{141}$ See Bailey, 'Restrictions of Competition by Object under Article 101 TFEU' (n 14), 582f.; Kolstad (n 18), 16; comp Jones, Sufrin, and Dunne (n 5), 225.

142 See C-373/14 P Toshiba Corporation v Commission ECLI:EU:C:2016:26, para 29; see also C-469/15 P FSL and Others v Commission ECLI:EU:C:2017:308, para 107; Jones, Sufrin, and Dunne (n 5), 225; Bailey, Bellamy \& Child (n 7), 167; Van Bael \& Bellis (n 10), 65; Whish and Bailey (n 10), 126.
} 
AG Bobek has proposed the understanding that the relevant competition authority must "check that there are no specific circumstances that may cast doubt on the presumed harmful nature of the agreement in question." "143 In consequence, consideration to all circumstances would be required, since the existence of circumstances establishing doubt could otherwise not be ruled out. Arguably, consideration to all circumstances is not impeccably aligned with either the administrative efficiency objective of restrictions by object, ${ }^{144}$ or the expression that contextual consideration may be limited to what is necessary. ${ }^{145}$ Considering context only in uncertain (borderline) cases could not remedy these problems; ${ }^{146}$ namely, uncertainty may depend on the context, to begin with, ${ }^{147}$ and context must be considered in all cases. ${ }^{148}$

Another understanding emerges from the CJ's judgment in Generics. The court declared that once the responsible competition authority has proven, according to the requisite standard of proof, that the common denominators are met, the disputed agreement "must, in principle, be characterised as a 'restriction by object"'. ${ }^{149}$ Once that is accomplished, the defendant has to produce counterproof of contextual anomalies capable of causing reasonable doubt as to the reliance in casu on the experience of the effects of the common denominators and thus to the alleged anti-competitive object. ${ }^{150}$ If the defendant produces such counterproof, the pendulum returns to the responsible authority that might have to undertake further necessary considerations to contextual factors to re-discharge the burden of proof. ${ }^{151}$

\section{CONCLUDING ELABORATIONS}

A by object type of collusion can be described as an abstract and general rule created through inductive reasoning based on experience. The experience includes previous case-law as well as other knowledge such as economic theory. Sufficiently reliable and robust, including sufficiently general and consistent, experience makes it possible to discern certain traits (common denominators) shared by several collusive conducts. These collusive conducts may be considered harmful by their nature if they are sufficiently likely to cause sufficient harm to competition. Through inductive reasoning, the common denominators discerned can be adopted as 'conditions' in a general rule (the by object type of collusion). This rule can be deductively applied on future agreements, rendering an effects assessment superfluous for establishing a restriction of competition.

For a disputed agreement to be restrictive by object, the responsible competition authority must prove that it meets the common denominators of a by object type of collusion, considering content, objectives, and context. The burden of proof is no longer

\footnotetext{
143 See C-228/18 Budapest Bank, opinion of AG Bobek (n 34), para 48.

144 Comp n 14.

145 See n 142.

146 See for such considerations Ioannidou and Nowag (n 10), 363.

147 Comp C-209/07 BIDS, opinion of AG Trstenjak (n 116), para 59; C-307/18 Generics (n 11), para 107;

Kolstad (n 18), 16.

148 See n 69.

149 See C-307/18 Generics (n 11), para 95.

${ }^{150}$ See, for that effect, C-307/18 Generics (n 11), paras 96-111; C-307/18 Generics, opinion of AG Kokott (n

61), para 149; C-591/16 P Lundbeck (n 11), paras 119-128.

${ }^{151}$ Comp C-469/15 P FSL (n 142), para 108.
} 
discharged if the defendant produces arguments (counterproof) about contextual anomalies which render doubtful the reliance on experience in casu as to the effects of agreements featuring the common denominators (the experienced effects). The defendant's arguments must be relevant. Relevant arguments should bring reasonable doubt to the experienced effects - any doubt must benefit the defendant. Such arguments should substantiate circumstances in casu additional to the common denominators (i.e. contextual anomalies) which may be pro-competitive compared to the experienced effects; naturally, arguing that the contextual anomalies are aggravating (or not affecting) the experienced effects would not call the experienced harmful nature in question. Furthermore, it is insufficient for the defendant to argue that the contextual anomalies bring countervailing efficiencies - such efficiencies are assessed only under Article 101(3) TFEU. Instead, the arguments must question the experienced effects, to begin with.

In no part of the assessment of a restriction by object is it relevant to examine the effects of the disputed agreement. Firstly, context is separate from effects. Secondly, consideration to contextual anomalies concerns not whether it is likely or unlikely that the disputed agreement will have specific effects. Instead, relevant is only the possibility to rely on the experienced effects. If experience can be relied on, the agreement is subsumed under a by object type of collision, rendering it harmful by its nature and its effects superfluous to consider. However, if reasonable doubts exist as to the experience after having considered arguments about contextual anomalies, the agreement cannot be considered harmful without assessing its effects to ensure whether the arguments are correct.

To widen the perspective, the approach I present seemingly pursues the objectives of restrictions by object and Article 101 TFEU in a balanced manner. It facilitates legal certainty by adopting only one relatively simple and (possible to make) clear requirement. Additionally, it facilitates administrative efficiency by neither requiring consideration to effects nor all circumstances of a case, but only to the reliability of experienced effects. Consequently, it facilitates effectiveness in prohibiting anti-competitive agreements. Simultaneously, it facilitates a restrictive interpretation and the avoidance of false positives by allowing defendants to avoid by object restrictions merely by adducing reasonable doubts. In sum, the approach appears to reasonably balance the relevant objectives.

Concludingly, it can be assumed that a distinction between restrictions by object and effect is possible to uphold. For a restriction by object, it suffices that the disputed agreement can be subsumed under a by object type of collusion. Such subsumption requires consideration to content, objectives, and context of the disputed agreement in comparison with experience of by object types of collusion. The relevant question is only whether the experience can without reasonable doubt be applied in casu for declaring the disputed agreement harmful by its nature. 


\section{LIST OF REFERENCES}

Amato F, 'Defining Agreements and Concerted Practices Restricting Competition in EU Competition Law' in Cortese B (ed), EU competition law: Between Public and Private Enforcement (Kluwer Law International 2013)

Bailey D, 'Article 101(1)' in Bailey D, and John LE (eds), Bellamy \& Child: European Union Law of Competition (8th edn, Oxford University Press 2018)

Bailey D, 'Restrictions of Competition by Object under Article 101 TFEU' (2012) 49(2) CML Rev 559

Craig P, and De Burca G, EU law: Text, Cases and Materials (7th edn, Oxford University Press 2020)

DOI: https://doi.org/10.1093/he/9780198856641.001.0001

Faull J, and others, 'Article 101' in Faull J and Nikpay A (eds), Faull \& Nikpay: the EU law of competition (3rd edn, Oxford University Press 2014)

Friend M, 'Restrictions by Object Under EU Competition Law' (2020) 79(3) CLJ 423

DOI: $10.1093 /$ law/9780199665099.001.0001

Ibáñez Colomo P, and Lamadrid A, 'On the Notion of Restriction of Competition: What We Know and What We Don't Know We Know' (SSRN 2016) $<$ https://papers.ssrn.com/sol3/papers.cfm?abstract_id=2849831> accessed 27 March 2021

Ioannidou M, and Nowag J, 'Can two wrongs make it right? Reconsidering minimum resale price maintenance in the light of Allianz Hungária' (2015) 11(2-3) European Competition Journal 340

DOI: https://doi.org/10.1080/17441056.2015.1080044

Jones A, Sufrin B, and Dunne N, Jones \& Sufrin's EU Competition Law: Text, Cases, and Materials (7th edn, Oxford University Press 2019)

DOI: https://doi.org/10.1093/he/9780198824657.001.0001

Kolstad O, 'Object contra effect in Swedish and European competition law' (Uppdragsforskningsrapport 2009:3, Konkurrensverket: Swedish Competition Authority 2009)

Odudu O, 'Restriction of Competition by Object - What's the Beef?' (2009) 8(1) Comp Law 11

Peeperkorn L, 'Defining “By Object” restrictions' (2015) 3 Concurrences 40 
Stefanowicz O, 'Guidance on the Limits for the Use of Restrictive Clauses in Commercial Lease Agreements: Once Again on Restrictions by Object' (2016) 9(14) Yearbook of Antitrust and Regulatory Studies 279

DOI: https://doi.org/10.7172/1689-9024.yars.2016.9.14.14

Tannenbaum S, 'The concept of the restriction of competition 'by object' under article 101(1)’ (2015) 22(1) MJECL 138

Van Bael \& Bellis, Competition Law of the European Union (6th edn, Kluwer Law International 2021)

Wahlin M, 'Post-Cartes Bancaires: Restrictions by Object and the Concept of Vertical Hardcore Restrictions' (2014) 13(4) Comp Law 329

Whish R, and Bailey D, Competition Law (8th edn, Oxford University Press 2018 DOI: https://doi.org/10.1093/law:ocl/9780199660377.001.0001 